\title{
AUDIOVISUAL COMMUNICATION IN CULTURAL SPACES
}

COMUNICAÇÃO AUDIOVISUAL EM ESPAÇOS CULTURAIS

\section{Joel Felipe Guindani}

Doutor em Comunicação e Informação pela Universidade Federal do Rio Grande do Sul (Porto Alegre/Brasil).

Docente Adjunto na Universidade Federal de Santa Maria (Santa Maria/Brasil).

E-mail: joel.guindani@ufsm.br

\section{Priscila Bicca Urach}

Pós-graduada em Administração e Marketing pela Centro Universitário Internacional (São Borja/Brasil).

E-mail: priscila.urach@cvale.com.br

\section{Eloísa Sampaio}

Graduada em Tecnologia em Produção Cênica pela Universidade Federal do Paraná (Curitiba/Brasil).

E-mail: eloisasampaio1@gmail.com 


\section{Brazilian

\section{ABSTRACT}

This paper ${ }^{1}$ aims to reflect on the relationship between audiovisual communication and cultural spaces, specifically the Cultural Association of Bossoroca (ACB), located in the border region of Missões, in the town of Bossoroca. Theoretically, it proposes the elucidation of the notion of audiovisual communication related to the management of information in the context of digitalization and technological virtualization and as a communication process of the Creative Industry. As a methodology, this paper makes use of digital media observation, collection, and qualitative analysis. The field research starts from the observation and mapping of communication platforms and contents of the ACB, and ends by pondering audiovisual as an important communication process to the management of cultural spaces.

Keywords: Audiovisual Communication. Information. Creative Industry. Culture. ACB.

\section{RESUMO}

Este artigo tem como objetivo refletir sobre a relação entre a comunicação audiovisual e os espaços culturais, mais especificamente a Associação Cultural de Bossoroca (ACB), localizada na região fronteiriça de Missões, no município de Bossoroca. Teoricamente, propõe a elucidação da noção de comunicação audiovisual relacionada à gestão da informação no contexto da digitalização e virtualização tecnológica e como processo de comunicação da Indústria Criativa. Como metodologia, este artigo faz uso da observação, coleta e análise qualitativa em mídias digitais. A pesquisa de campo parte da observação e mapeamento das plataformas e conteúdos de comunicação do ACB, e termina por ponderar o audiovisual como um importante processo de comunicação para a gestão dos espaços culturais.

Palavras-chave: Comunicação Audiovisual. Informação. Indústria Criativa. Cultura. ACB.

\footnotetext{
${ }^{1}$ Article originally written in Portuguese and translated to English by Thomás Czrnhak. E-mail: thomasbczrnhak@gmail.com
} 


\section{Brazilian

\section{INTRODUÇão}

The scientific analysis of communicational problems or solutions, also seen as phenomena of the Creative Industries, bring together fields of knowledge such as cultural spaces and audiovisual communication. Thus, this paper aims to reflect on the relation between audiovisual communication and cultural spaces, specifically from the communication actions undertaken by the Cultural Association of Bossoroca (ACB), located in the border region of Missões, in the town of Bossoroca. As of methodology, it makes use of the observation of digital media, collection and qualitative analysis (NEVES, 1996). The field research initially takes place from the observation and mapping of communication platforms and contents of the $A C B$, ending with the understanding of the audiovisual as a communication process of the creative industries, especially of information management of cultural institutions, while anchored in knowledge about communicational "know-how".

Theoretically, it proposes the elucidation of the notion of audiovisual communication related to the possibility of information management and memory, as well as a communication process and as a creative industry within the scope of digitalization and technological virtualization, those which increasingly demands more attentive and strategic management.

Ultimately, it is observed that the relation between theory and practice (that is, the relation between doing and knowing about doing) in the scope of the diversity of digital and virtual technologies, concerns the importance of a permanent management of audiovisual communication of the ACB. It is also observed that audiovisual communication in this cultural space has the potential to go beyond knowing how to broadcast sporadically - or simple archiving - and become a broader, creative and strategic communicational process.

\section{AUDIOVISUAL AS A CREATIVE INDUSTRY AND A COMMUNICATIONAL PROCESS OF MEMORY}

In the book "New Audiovisual Forms", Santaella considers that the amount of images produced after the invention of technologies means a time of images mixture (2016). It is realized that this mixture can be a symptom not only of the speed of production and dissemination of these images, but also of an incipient reflective practice. The importance of a more attentive reflection - and one that generates more solid processes and strategies both on the production and management of images - is the first step of understanding of these contemporary problems, whether the accumulation, mixture or even the erasure and invisibility of collections, heritage and memories of cultural spaces. 


\section{Brazilian \\ Creative Industries}

Thus, the proposal to think the audiovisual not only as a technique, but as a communication process, also corroborates the importance of attentive, deep, complex and critical thinking through this time of "liquid languages, in this era of increasingly less confined mobile communication to fixed places"1 (SANTAELLA, 2016, p. 09).

Also, we can think, from the perspective of language liquidity, that the notions of archive and collection enter into this logic of the porosity of borders that until then distinguished and separated technologies and their contents through supports and locations enclosed in formats and genres, the which also assisted in the management of information, collections, heritage and institutional memory. ${ }^{2}$

The expansion of technologies and, obviously, the production of audiovisual images opened up communication as a more difficult and laborious phenomenon to do and, above all, to understand. ${ }^{3}$ In other terms, both the audiovisual production and the knowledge about what comes from communication itself as a broader concept ${ }^{4}$ is the initial challenge when we propose to think about the management of a cultural space, especially when other issues related to the need for collection management and institutional memory.

The conceptual and empirical relationship between cultural spaces and audiovisual communication requires us to observe and contemplate the notion of memory not only related to its semantic history, but also in the sense of the present time, especially when the intention is to understand the construction and strengthening of identity processes, sociability, the forms of management and mobilization of audiences in these cultural spaces. It is worth noting that the reconstruction of memories - whether through collection or archive -, in the sense of the present time, is a way to revive the communicational capital that already exists and is necessary for the life of these spaces: "the time of places, this is a precise moment where an immense capital that we lived in the intimacy of a memory disappears, only to live under the gaze of a reconstructed history" (NORA, 1993, p. 09).

\footnotetext{
${ }^{1}$ Our translation.

${ }^{2}$ Containing or managing the risk of erasing an institutional memory should be a concern of all cultural institutions and a task that begins with "management and preservation, especially digital", associated with a professional role (MARCIAL; VIEIRA, 2021).

${ }^{3}$ Lipovetsky \& Serroy (2009. p. 98) help us to think of the present as an economy of an equally complex symbolic order: "creative 'trans-aesthetic' capitalism does not work on the basis of separation, division, but rather of crossing, the overlapping of domains and genres."

${ }^{4}$ We also consider it important to contextualize "communication" as a process, something that takes place over time and, therefore, begins and develops, ending up as a cycle. However, it does not die out as a process: it continues to be fueled and reestablished by responses, feedback, feedbacks and reactions (IASBECK, 2010, p. 16).
}

${ }^{5}$ Our translation. 


\section{Brazilian \\ Creative Industries}

The audiovisual communication from the perspective of memory reconstruction can also be understood as audiovisual documentation. The Brazilian Dictionary of Archival Terminology (2005, p. 73), classifies audiovisual documentation as a "documental genre integrated by documents that contain images, fixed or in motion, and sound recordings, such as magnetic films and video tapes ${ }^{6 \prime}$. It is worth clarifying that the notion of audiovisual communication is conceived in this paper in order to contemplate or observe not only moving images, but also still ones, that is, photographic products, graphic and visual arts, among others. It is also possible to consider audio products as audiovisual communication, whether advertising or phonographic pieces placed on supports such as Cassette Tapes, Discs, CDs and DVDs.

The doing, or the practical task of audiovisual documentation - as a duty/problem of all cultural spaces - also provokes us to think about communication in the perspective of processuality and, in the same way, helps us to understand the intersections between communication, creative industry and cultural activities carried out in these cultural spaces.

Hence, thinking about audiovisual as a communication process and as a powerful capital for the expansion of document management in a cultural space is only possible when we also propose to think about strategic communication? based on knowledge in the field of Communication as a Creative Industry. For this, it is important to note that audiovisual communication as a creative industry is not just about a technical perspective, or solely about an instrumental know-how "at the service of" cultural spaces. In other words, from the perspective of communication as a creative industry, it is important to note that audiovisual communication is in line with the need for complex thinking in communication itself as a process of production of broad knowledge and that, equally, delegates challenges to the cultural spaces. That is because audiovisual communication - and cultural spaces that are not exempt from the task of information management - need to advance from "knowing-how" to "knowing about doing", an advance that we consider important for the thinking and doing of audiovisual communication as a creative industry.

For Feitosa and Belochio (2018), the domain of "knowing how to do" and "knowing about doing" is crucial for the comprehension of cultural phenomena that do not require communicational actions. The domain of "knowing-how" matches strategies and knowledge, for example, in the scope of production, about making images as appropriate languages for a specific audience, etc. The "knowing about doing", on the other hand, is consistent with the domain of knowledge about how to develop each stage of the process or audiovisual product, always in a complex, procedural and permanent perspective. Expressly,

\footnotetext{
${ }^{6}$ Our translation.

${ }^{7}$ The notion of strategic communication problematizes the linear, instrumental and technical view that is still predominant and which simplifies communication as a less important practice or easy to manage (KUNSCH, 2018).
} 


\section{Brazilian \\ Creative Industries}

"knowing about doing" makes us aware that, in addition to technical and instrumental knowledge, audiovisual communication does not require the production of knowledge that is not only constant, but also organized and systematized.

"Knowing about what to do" therefore requires the observation of various instances ranging from "handling" equipment/technologies to the perception of language and audiences in relation to attributes such as the vision, values and objectives of the cultural space. In essence, "knowing about doing" is not just a domain of technical or instrumental knowledge, but of broad knowledge that tunes in to the complexity of the problems and possibilities of audiovisual communication for and with cultural spaces.

\section{AUDIOVISUAL COMMUNICATION AND THE DIVERSITY OF SCREENS AND IMAGES}

This attentive look at the communicational process is also consistent with the phenomenon of the explosion of screens and images, which generated a certain excess of aestheticization and lack of information control (LIPOVETSKY; SERROY, 2011). However, concomitant to the lack of control, digital and convergent audiovisual communication significantly expanded the possibilities of usability for cultural spaces that deal with the issue of managing their collections. As never before, it is possible to disseminate content in different ways and the audiovisual potential can be considered a good option to carry out this process, as it is perceived that there is more and more integration between the media, mobile technologies and multiple screens, enabling the public the form of visualization connected and shared between individuals, institutions in increasingly unrestricted time and space.

The informational speed, like the access to ample communicational data, is made by the multiplicity of screens: cell phone screens, projection screens, cinema screens, computer screens, television screens, etc. In fact, new practices for viewing audiovisual content can be created in the mix of these screens and offers multiple forms of awareness, entertainment and audience engagement (MASSAROLO; MESQUITA, 2016).

Therefore, when we think about audiovisual and information management in cultural spaces, it is essential to perceive and analyze changes in the field of communication, which go far beyond the migration from analogue to digital. McLuhan (1975) made it clear that the medium is not a simple technical channel for passing content, or a simple vehicle for transmitting the message. The medium is a determining element of communicational processuality. According to this author, the means are extensions of our senses, functioning as a kind of prosthesis. Thus, smartphones or any other convergent device can be extensions 


\section{Brazilian \\ Creative Industries}

of our fingers or hands, and more, an extension of our mind, "configuring a symbiotic relationship between technology and humanity" (MCLUHAN, 1975, p. 21).

We understand that the production, management and dissemination of information is no longer only under the aegis of communication companies. Auto-media builds the culture of connection as a hybrid and emerging model not only in the production sphere, but in an informational circulation activated by people who can consume, produce and share through their own social media, with their fast and free access apps (CASTELLS, 2015).

This reflection on contemporary times increasingly managed and managed by image technologies is the first step towards thinking about the challenges and possibilities of audiovisual communication in cultural spaces. The diversity of screens and, consequently, of images, is an increasingly important place to stop and reflect for those who intend to manage audiovisual communication in cultural spaces.

\section{BRIEF CONTEXTUALIZATION OF THE CULTURAL ASSOCIATION OF BOSSOROCA - ACB}

The town of Bossoroca (RS) has peculiarities arising from the intertwining of signs and symbolic representations of this relationship between the diversity of local creative and cultural activities, the daily lives of residents and the sociability woven by the potential of local tourism. Bossoroca is located in the region of Missões, northwest of the State of Rio Grande do Sul, with a population of just over 6,000 inhabitants. On one hand, the calmness, considered by residents as a safe and pleasant place, and, on the other, the cultural movement, which attracts tourists, especially from the region and from South America. The municipality of Bossoroca is also perceived as a border territory and is located $510 \mathrm{~km}$ from Porto Alegre, the capital of the state.

The ACB is a cultural space, in the form of an association, founded in 1994, on the initiative of a group of 18 citizens from Bossoroca. It is a non-profit civil entity whose main objective is the integration of segments of the community, through artistic and cultural manifestations.

The entity promotes studies and disseminates different artistic expressions through various projects and public cultural events. It uses and plays a leading role in the visibility of the culture of the different regions of the state and also of the country and, in this way, stimulates the transformation of the local community, which sees the ACB as a center for cultural integration and development.

8 Our translation. 


\section{Brazilian \\ Creative Industries}

ACB's projects receive financial support from individuals and legal entities, as well as funding made possible by the Lei de Incentivo Cultural (LIC), a law that provides financial incentives to cultural entities.

The main projects developed by ACB are:

Chart 1: ACB Cultural Projects

\begin{tabular}{|c|c|}
\hline Manancial missioneiro da canção & $\begin{array}{l}\text { Nativist/Missioner Festival, started in 1990, in which new songs } \\
\text { referring to themes about Bossoroca can be entered. Afterwards, } \\
\text { a CD with the winning and most popular songs is recorded. The } \\
\text { project is carried out on an annual basis with the South American } \\
\text { Folklore Meeting. }\end{array}$ \\
\hline Encontro sul-americano de folclore & $\begin{array}{l}\text { Inserted in the commemorations of the Municipal Folklore Week, } \\
\text { it is one of the most significant events in the region, promot- } \\
\text { ing the integration of Brazil with Argentina, Uruguay, Paraguay } \\
\text { and Chile. The project is carried out on an annual basis with the } \\
\text { Manancial missioneiro da canção. }\end{array}$ \\
\hline Bossoroca - um cantochão missioneiro & $\begin{array}{l}\text { Edition of a CD with the exclusive participation of musicians, po- } \\
\text { ets and composers from the town. The objective is to value and } \\
\text { promote the work of local artists. This project is carried out every } \\
\text { two years. }\end{array}$ \\
\hline Projeto Memória farroupilha & $\begin{array}{l}\text { With the first edition in } 2012 \text { and with the support of Eletrosul, } \\
\text { this project aims to transmit, through lectures to the young pub- } \\
\text { lic, teachings about traditionalism, showing history in a real way, } \\
\text { with due concern for the traditional aspects of the gaúcho culture } \\
\text { and missioneira. It is held annually as part of the Farroupilha Week } \\
\text { celebrations. }\end{array}$ \\
\hline 21 - Os anos que não foram escritos & $\begin{array}{l}\text { Video documentary, with testimonials from people in the region, } \\
\text { about the period of the military dictatorship, from } 1964 \text { to } 1985, \\
\text { with the main objective of taking this content to students and } \\
\text { teachers of elementary and high school levels. Documentary is a } \\
\text { unique work and is aimed for the student community. }\end{array}$ \\
\hline Nossos valores - poetas em prosa e verso & $\begin{array}{l}\text { Collection of works in book - short stories, poems, chronicles and } \\
\text { accounts of people born in Bossoroca and also those who lived } \\
\text { there. Single Edition. }\end{array}$ \\
\hline Bossoroca em canto e dança. & $\begin{array}{l}\text { A collection of works in a book - short stories, poems, chronicles } \\
\text { and accounts of people born in Bossoroca and also those who } \\
\text { lived there. Single Edition. } \\
\text { Project carried out in partnership with the Municipal Govern- } \\
\text { ment, with the Municipal Social Assistance Secretariat and CRAS, } \\
\text { whose purpose is to show the work developed with young people } \\
\text { and children from local schools in free singing and dancing class- } \\
\text { es. Held annually within the city's end-of-year festivities. }\end{array}$ \\
\hline
\end{tabular}

Source: ACB, 2021 


\section{Brazilian Creative Industries}

\section{AN OVERVIEW OF ACB'S COMMUNICATION}

In this section, we begin the observation and diagnosis of ACB's communication. We seek to identify which dissemination channels - especially audiovisual communication - ACB uses with its audiences. In this first observation, we find the amount of: $01 \mathrm{Blog}$, 01 Facebook page and 02 Websites:

Figura 01: ACB's blog

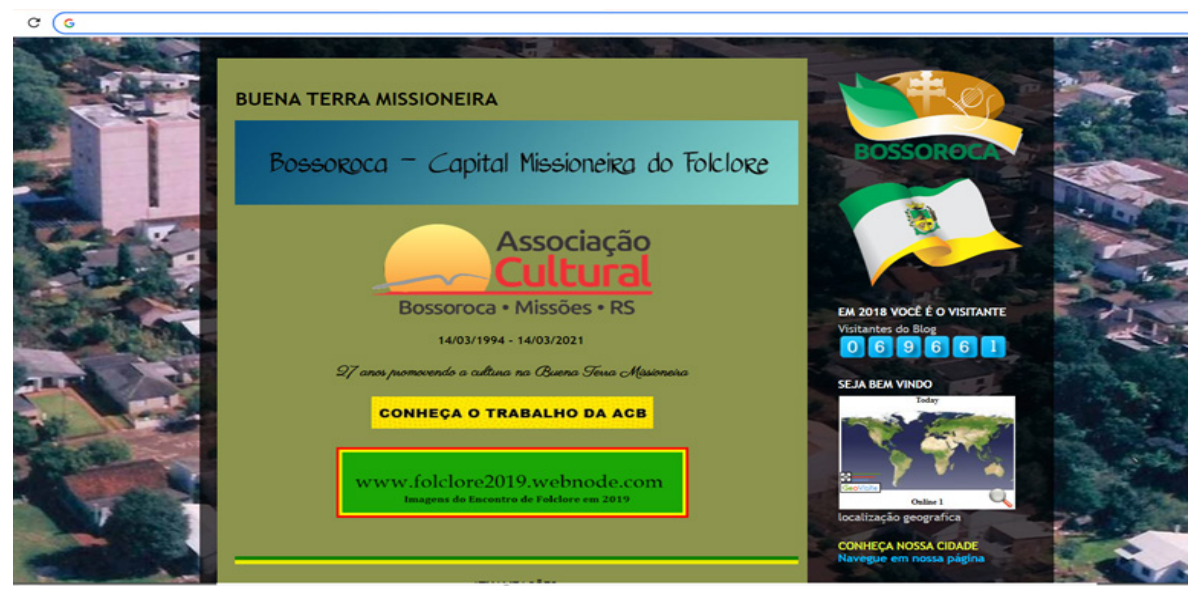

Source: http://bossorocars.blogspot.com (Accessed on 22/11/2021)

Figure 02: ACB's Facebook page

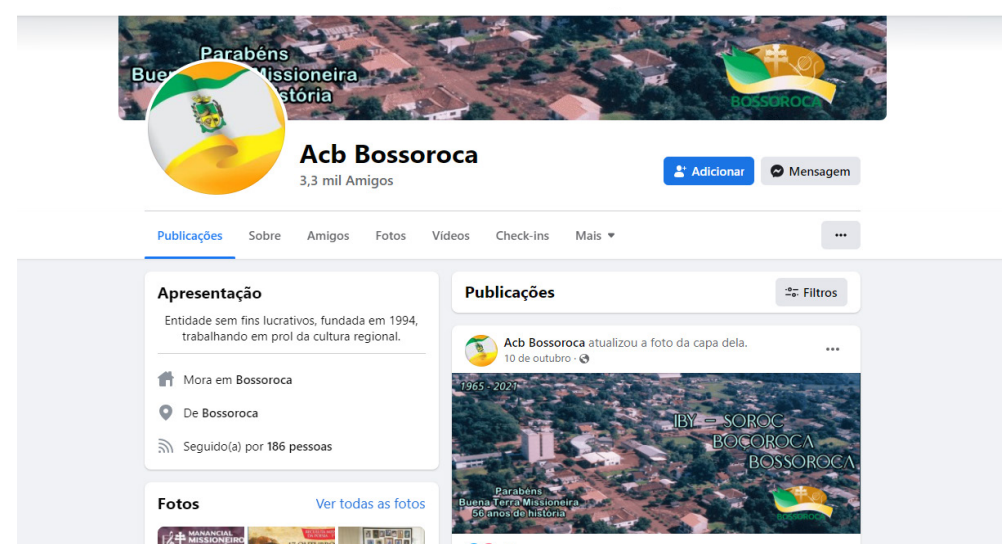

Source: www.facebook.com/acbossoroca (Accessed on 22/11/2021) 


\section{Brazilian Creative Industries}

Figure 03: ACB's first Website

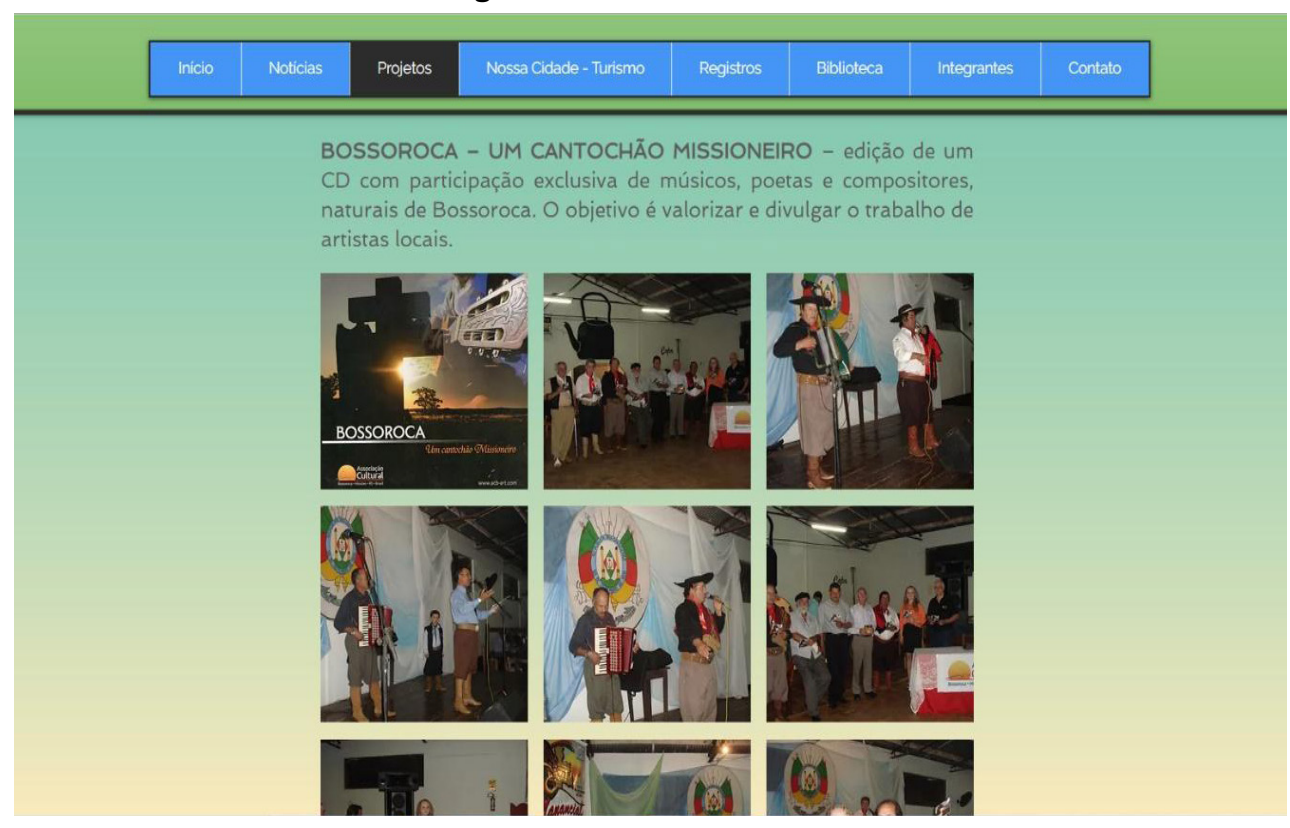

Source: https://acbossoroca.wixsite.com/cultura (Accessed on 22/11/2021)

Figure 04: ACB's second Website

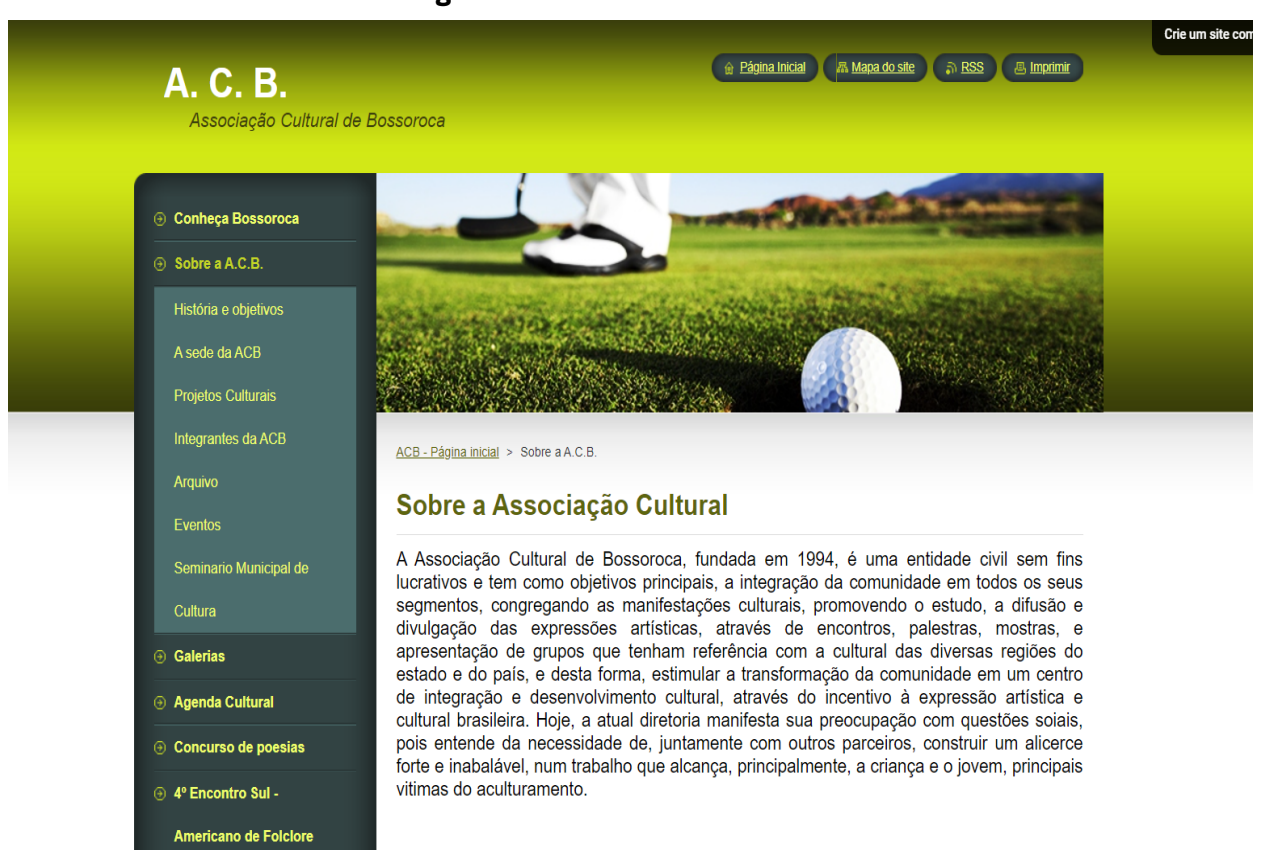

Source: https://acbossoroca.webnode.com.br/sobre-nos/ (Accessed on 22/11/2021) 


\section{Brazilian \\ Creative Industries}

We note that ACB uses two websites with similar content and objectives. In these spaces, we identify audiovisual elements that fit the duty of historical memory and visibility of the trajectory of projects already developed.

As we look at these communication platforms, we noticed some issues to consider. On the Facebook page, the most viewed post has 71 likes and refers to the South American Folklore Meeting, considered the most popular project by ACB. We realize that the timing of dissemination of this project is not constant or permanent.

Another point observed was "no privacy" of Facebook management, as the page is free to access and followers can post without any authorization or selection criteria. With the option "marking" the ACB, audiences/artists can share and give visibility to their content on the ACB timeline. We believe that this can generate risk to the communication management of the ACB, because it allows for a certain lack of control with regard to the dissemination criteria and, above all, the quality of the content made available. Here, we can see that the dimension of "knowing how to do", as a simpler and faster stage of a communication process, prevails over a communicational "knowing about doing".

As for the websites, both bring a little of the Association's history, main activities, photos and a description of the team, however, this duplication of website addresses generates confusion for the public - after all, are they from the same cultural association? Which should one access for official information?

The two websites are also not frequently updated, with the last news being published in 2019. However, there it is possible to make contact through e-mail, which we think is something positive and which is characterized as an open channel of communication with the its audiences. On the other hand, The Blog is the only tool that mentions the existence of another tool used, through a link (which refers to only one of the sites). On the blog there is also information about the ACB and a vast amount of material about local artists and about Bossoroca - although, equally, it is not updated nor managed very often.

Following up, we prepared a simple comparison of the dissemination tools. In the table below, significant elements regarding the materials presented and the monitoring of the public on the pages we observe are evaluated. 


\section{Brazilian Creative Industries}

Table 01: Assessment of communicative elements regarding communication tools associated with the audiovisual of the ACB

\begin{tabular}{|c|c|c|c|c|c|}
\hline Page & $\begin{array}{c}\text { Monthly updates } \\
\text { frequency }\end{array}$ & Written materials & Videos & $\begin{array}{c}\text { Audio and } \\
\text { podcast }\end{array}$ & Public Monitoring \\
\hline $\begin{array}{l}\text { Bossoroca RS blog } \\
\text { page. }\end{array}$ & $\begin{array}{l}\text { Average of } 01 \\
\text { publication every } \\
\text { two months. }\end{array}$ & Yes. & Yes, 11 & No. & $\begin{array}{l}\text { 68,123 visits on } \\
7 / 26 / 2021 \\
27 \text { Followers. }\end{array}$ \\
\hline $\begin{array}{l}\text { ACB Bossoroca Face- } \\
\text { book Page. }\end{array}$ & $\begin{array}{l}\text { A new post every } \\
\text { three day. }\end{array}$ & $\begin{array}{l}\text { Little writing, fo- } \\
\text { cus on Videos and } \\
\text { Images. }\end{array}$ & Yes, 38. & No. & $\begin{array}{l}3.302 \text { friends, } \\
192 \text { followers. }\end{array}$ \\
\hline $\begin{array}{l}\text { Website 1: } \\
\text { ACB Bossoroca Wix }\end{array}$ & $\begin{array}{l}\text { Last post was in } \\
2019 .\end{array}$ & $\begin{array}{l}\text { Good presentation } \\
\text { of projects, library } \\
\text { and events, despite } \\
\text { being outdated. }\end{array}$ & $\begin{array}{l}\text { Yes, 6, all out- } \\
\text { dated. }\end{array}$ & No. & $\begin{array}{l}0 \text { followers, and no } \\
\text { visitor map }\end{array}$ \\
\hline $\begin{array}{l}\text { Website 2: } \\
\text { acbossoroca.web- } \\
\text { node }\end{array}$ & $\begin{array}{l}\text { There are no reg- } \\
\text { ular publications, } \\
\text { the last being in } \\
\text { October } 2014 . \\
\text { Website created } \\
\text { in } 2011 .\end{array}$ & $\begin{array}{l}\text { Yes, good presen- } \\
\text { tation and organi- } \\
\text { zation of the page. }\end{array}$ & Yes, 8. & No. & $\begin{array}{l}0 \text { followers, and no } \\
\text { visitor map }\end{array}$ \\
\hline
\end{tabular}

Source: Research and organization by the authors (2021)

As a way to better visualize the placement and access to audiovisual content, we created the following chart:

Graph 01: Mapping of audiences, pages and number of updates

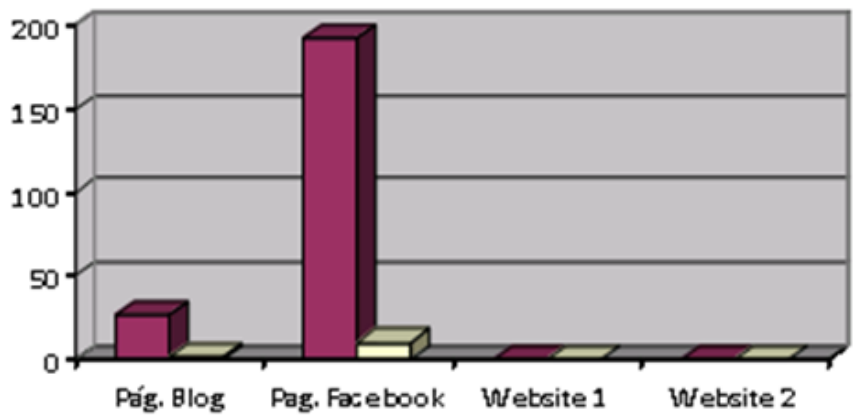

Grafico de mapearnento de públios des páginas

\begin{tabular}{l}
\hline Seguido res \\
$\square$ Periodicidade de At ul izaçōes ao \\
mês
\end{tabular}

Source: Authors' formulation (2021) 


\section{Brazilian \\ Creative Industries}

We emphasize that, for a more proactive use of the existing tools in favor of the dissemination of the work carried out by the ACB, it is necessary to use these online pages for interactive demonstrations of the published work. For example, Blog Bossoroca RS has had more than 68 thousand views since its creation in 2018. This Blog features mostly audiovisual content such as photographs accompanied by written materials about projects and events held in partnership with municipal public authorities and institutions. We see as possible and urgent the need to present audiovisual content to the public with more quantity, quality and frequency, especially in video format.

We realized that Facebook is the audiovisual communication platform with more daily movement because it is used by followers who share content relatively frequently. Nevertheless, the use of audiovisual resources with strong potential for engagement was not identified, such as livestreams based on themes and subjects relevant to the ACB. Through the totality of audiovisual content broadcast, we see as important the production of an account/profile on Instagram, an online social network that would increase the consumption of photos and videos among the following audiences. Instagram would also allow for some interaction with other languages, as it makes it possible to apply digital filters and share them with other media such as Facebook, Twitter, Tumblr and Flickr. At the end of the observation, we identified that many audiovisual contents are also stored digitally, in products such as CD's and DVD's.

\section{GENERAL PROVOCATIONS ABOUT ACB AUDIOVISUAL COMMUNICATION}

From an observation of the ACB's virtual communication platforms, some provocations arose and help us to better reflect on the notion of audiovisual communication related to the challenges and possibilities of information and memory management as a communication process, in the case observed, sometimes done in a disjointed way of knowing about doing, and sometimes moved by the spontaneity of its public followers. This consideration came from our observation of the content freely conveyed by the various audiences on the ACB Facebook page and caused us to think that the relationship - and an inseparable condition - between audiovisual communication and cultural spaces, should be established under a thought that is not just careless, sporadic and punctual know-how. It must be a conscious know-how, that is, a knowledge of what to do as the materialization of an attentive, strategic, conscious communication arising from a professional intention.

We understand, therefore, that the audiovisual communication conveyed in the four researched digital communication tools is not adequately explored, and its procedural potentials are little explored, especially because the forms of transmission and update periodicity are not objects of planning. Consequently, this does not contribute to building and consolidating ACB's identity as a cultural group that 


\section{Brazilian \\ Creative Industries}

produces and manages its audiovisual communication. It is not visible or communicated in the investigated communication vehicles that the ACB does not yet have an active or formalized communication sector in its management or administration structure. In other words, it is possible to infer that the audiovisual communicational "knowing about doing" is not part of the organicity or organic structure of this cultural space.

As a possible alternative, the strategic and procedural know-how of audiovisual communication can take advantage of this already existing cultural capital and thus potentialize new audiences and spectators from inside and outside the city, mainly because Bossoroca is a cultural territory with an international frontier and, therefore, with a strong identity relationship with other subjects and countries in Latin America.

\section{CLOSURE: FINAL CONSIDERATIONS}

Muniz Sodré (2006) encourages us to think of the notion of audiovisual communication as relating to the cognitive condition and its realization resulting from a rational process of choices always guided by conditions determined by the context. We know, therefore, that these choices are flexible and adaptable to the circumstances in which they take place, as long as they are integral and not alien to knowledge about organized and conscious action. Digital audiovisual communication in a network and as a conscious, procedural and strategic action can expand the possibilities of relating cultural spaces with their audiences, especially in this time of dizzying increase in the consumption of screens and image production.

The convergence between communication technologies is irreversible, and this convergence is what expands our communicational potential across multiple screens - cell phone screens, cinema screens, computer screens, etc. - , as well as the access and consumption doors that open to the creation of new relationships between cultural spaces and their audiences. In summary, we find that the efficiency of audiovisual communication - whether as a support for other sectors of the creative economy -, to the needs of information management, is the result not only of sporadic know-how, but also of knowledge about procedural and strategic action.

Finally, we realize that audiovisual communication, to be better constructed and managed, can be articulated with other knowledge coming from, for example, Journalism, Advertising and Publicity, Public Relations, Marketing, among others. Because knowledge about audiovisual production has become, in recent years, in addition to being complex and interdisciplinary, a condition for the development, management and prominence of communication in any cultural space. 


\section{Brazilian Creative Industries}

\section{REFERENCES}

CASTELLS, Manuel. $\mathbf{O}$ poder da comunicação. Trad. Vera Lúcia Mello Joscelyne. 1st ed. São Paulo/Rio de Janeiro: Paz e Terra, 2015.

FEITOSA, Sara A.; BELOCHIO, Vivian C. Quatro relações entre Comunicação e Indústria Criativa. In: SILVA, Marcela Guimarães e; GUINDANI, Joel Felipe. (Org.). Comunicação e Indústria Criativa: políticas, teorias e estratégias. 1st ed. Jaguarão: CLAEC, 2018.

IASBECK, Luiz Carlos Assis. Ouvidoria é comunicação. Revista USP, v. 7, n. 12, 2010. Available at: https:// www.revistas.usp.br/organicom/article/view/139045. Acessed on: 01 jun. 2021.

KUNSCH, Margarida M. Krohling. A comunicação estratégica nas organizações contemporâneas. Media \& Jornalismo, 18(33), p. 13-24, 2018.

LIPOVETSKY, Gilles; SERROY, Jean. A Tela Global: mídias culturais e cinema na era hipermoderna. Porto Alegre: Ed. Sulina, 2009.

MARCIAL, E.; VIEIRA, J. da S. Memória institucional em Risco. Revista Ibero-Americana De Ciência Da Informação, 14(1), p. 150-170, 2021.

MASSAROLO, João Carlos; MESQUITA, Dario. Vídeo sob demanda: uma nova plataforma televisiva. Online, 2016. Available at: www.compos.org.br/biblioteca/compos2016videosobdemanda_3397.pdf. Acessed on: 27 jun. 2021.

MCLUHAN, M. O meio é a mensagem. In: MCLUHAN, M. Os meios de comunicação como extensão do homem (understanding media). São Paulo: Cultrix, 1975.

NEVES, José Luis. Pesquisa Qualitativa - Características, usos e possibilidades. Cadernos de pesquisa em Administração, São Paulo, v. 1, n. 03, 1996, p. 01-05.

NORA, Pierre. Entre memória e história: a problemática dos lugares. Revista Projeto História, São Paulo, n. 10, p. 7-28, dez. 1993, p. 4-14.

SODRÉ, Muniz. Antropológica do Espelho: uma teoria da comunicação linear em rede. Petrópolis, RJ: Vozes, 2002, p. 268. 